BJHS 53(4): 527-551, December 2020. C The Author(s), 2020. Published by Cambridge University Press on behalf of British Society for the History of Science. This is an Open Access article, distributed under the terms of the Creative Commons Attribution licence (http:// creativecommons.org/licenses/by/4.0/), which permits unrestricted re-use, distribution, and reproduction in any medium, provided the original work is properly cited. doi:10.1017/S0007087420000370 First published online 14 October 2020

\title{
The ciné-biologists: natural history film and the co-production of knowledge in interwar Britain
}

\author{
MAX LONG"
}

\begin{abstract}
This article analyses the production and reception of the natural history film series Secrets of Nature (1919-33) and its sequel Secrets of Life (1934-47), exploring what these films reveal about the role of cinema in public discourses about science and nature in interwar Britain. The first part of the article introduces the Secrets using an 'intermedial' approach, linking the kinds of natural history that they displayed to contemporary trends in interwar popular science, from print publications to zoos. It examines how scientific knowledge was communicated in the series, especially the appeal to everyday experience as a vehicle to engage mass audiences with scientific subjects. The second part examines the Secrets series through the lens of knowledge co-production, detailing how a range of different figures, including academic scientists, nature photographers, producers and teachers, became entangled in making the films. Recovering the term 'ciné-biology', it argues that Secrets developed a unique style of filmmaking that generated cultural space for the life sciences in British popular culture. The third part analyses two interwar cinema experiments to explore how audiences, imagined and real, shaped the kinds of natural knowledge characterized by the Secrets films.
\end{abstract}

On the night of 5 November 1930, a 'Gala Presentation of British Films' at the Imperial Conference in London featured an intriguing film about fungi growth. ${ }^{1}$ Plants of the Underworld was the latest in a series of shorts which the film historian Rachael Low called 'one of the few bright features of the British film industry during the twenties'. ${ }^{2}$ Secrets of Nature was a popular phenomenon: its films were viewed by millions in cinemas across the country. The series' success is suggested partly by its longevity: 144 films were made between 1919 and 1933 by British Instructional Films (BIF). In 1934 H. Bruce Woolfe, who conceived the series after reading Gilbert White's Natural History of Selborne, transferred his team, including producer Mary Field and photographer F. Percy Smith, to Gaumont-British Instructional (GBI). With guaranteed distribution to Gaumont cinemas, they released a further eighty-eight films under the

* PhD Candidate, History Faculty, University of Cambridge, UK. Email: mel58@cam.ac.uk.

The author would like to thank Peter Mandler, Helen Curry, Oliver Gaycken, Frankie Dytor, Freddy Foks, Anna Parker, Jean-Baptiste Gouyon, Tim Boon, Laura Carter, Lynton Lees and the members of the New YorkCambridge Training Collaboration (NYCTC), as well as the two anonymous referees, for their generous and insightful comments. Funding for this project was provided by the Wolfson Postgraduate Scholarship in the Humanities.

1 The Bioscope, 5 November 1930, pp. 74-98.

2 Rachael Low, History of British Film, vol. 4: 1918-1929, London: Routledge, 1997, p. 130. 
new title Secrets of Life, making a total of 232 films produced between 1919 and $1947 .^{3}$ Genre-defying and innovative, Secrets were analogous to the better-known British documentary movement's films. John Grierson and Paul Rotha were enthusiastic about the series and Stephen Tallents, the public-relations pioneer behind the Empire Marketing Board, called them 'morsels of good fortune'. ${ }^{4}$ Secrets were shown at the London Film Society and at local film societies; they had the backing of a cultural elite intent on 'improving' public taste, and were viewed as a high-quality, internationally competitive cultural export. ${ }^{5}$

This article analyses the production and reception of Secrets of Nature/Life, asking what these films tell us about cinema, the life sciences and popular culture in interwar Britain. The films were undoubtedly 'popular' in the sense that they had a large audience, and I use the term to refer to this mass reach rather than to distinguish between 'academic' and 'lay' science. That such distinctions are unhelpful, and at worst highly misleading, has long been established. ${ }^{6}$ However, whilst the nineteenth century has provided a rich arena for understanding how scientific knowledge was produced, circulated and consumed in a social context, the first half of the twentieth century has received considerably less attention. ${ }^{7}$ As Peter Bowler has shown, during this period self-styled scientific 'experts' adopted an impressive assemblage of massmedia technologies and played an 'active role in satisfying the increased demand for information'. ${ }^{8}$ But these individuals, who appeared in newspapers and periodicals and on the radio, were a disparate crowd, many of them far removed from 'academic' science. The exponential growth in print circulation, beginning in the nineteenth century, also meant that information could reach a wider and more engaged public, thereby increasing participation in scientific culture. 9 This was especially true of the life sciences, where 'natural history' served as a catch-all phrase that could include everything from amateur nature study to emerging disciplines like ecology. 10

3 Mary Field and Percy Smith, Secrets of Nature, London: Faber and Faber, 1934, pp. 239-42; Mary Field, 'Secrets 1919-1940', Documentary News Letter (1941) 2, pp. 3-6. See also Jlewis, 'A shortie checklist: British Instructional, Gaumont-British \& Rank', TCM Message Board, 15 June 2017, at https://forums.tcm.com/topic/ 139415-a-shortie-checklist-british-instructional-gaumont-british-rank, accessed 28 August 2020.

4 Scott Anthony, Public Relations and the Making of Modern Britain, Manchester: Manchester University Press, 2012, p. 222.

5 Laura Marcus, The Tenth Muse: Writing about Cinema in the Modernist Period, Oxford: Oxford University Press, p. 239.

6 James Secord, 'Knowledge in transit', Isis (2004) 95, pp. 654-72; Roger Cooter and Stephen Pumfrey, 'Separate spheres and public places: reflections on the history of science popularization and science in popular culture', History of Science (1994) 32, pp. 237-67.

7 For instance, Bernard Lightman, Victorian Popularizers of Science: Designing Nature for New Audiences, Chicago: The University of Chicago Press, 2007.

8 Peter Bowler, Science for All, Chicago: The University of Chicago Press, 2009, p. 2.

9 Geoffrey Cantor, Gowan Dawson, Graeme Gooday, Richard Noakes, Sally Shuttleworth and Jonathan R. Topham (eds.), Science in the Nineteenth-Century Periodical, Cambridge: Cambridge University Press, 2004.

10 Peter Bowler, 'Discovering science from an armchair: popular science in British magazines of the interwar years', Annals of Science (2016) 73, pp. 89-107. 
However, Bowler's claim that science films reached only a 'small and self-selected audience' grossly underestimates the influence of science films on public discourse at this time. ${ }^{11}$ The emergence, at the turn of the century, of the moving image as a medium for scientific experimentation, visualization and communication, and its implications for visual scientific culture, are well documented. ${ }^{12}$ The enduring popularity of wildlife television has motivated a number of researchers to trace the genre from its origins to the present day, concentrating mainly on Britain and the US. ${ }^{13}$ The natural history genre appeared early in cinema history, and images of plants and animals combined elements of variety performance and lantern lectures. The primary precursors to Secrets were Charles Urban's science films of the 1900s and 1910s, shot by F. Martin Duncan and later F. Percy Smith, whose time-lapse and microcinematography techniques, first pioneered by Julius Ries and Jean Comandon, caused a sensation. ${ }^{14}$ These early forays were halted by the First World War, after which British cinema underwent radical change. During the interwar period, cinema attendance skyrocketed. By the 1930s, cinema had become, according to Jeffrey Richards, 'indisputably the most popular form of entertainment in Britain'. ${ }^{15}$ Far from serving niche viewers with a prior interest in science, therefore, Secrets addressed a mass general audience precisely as cinema became an indispensable part of the British cultural landscape.

Some of the problems with accounting for the growing influence of scientific 'experts', and the notion of 'popularization', can be addressed by observing how knowledge coproduction impacted popular representations of science like Secrets. Partly due to the term's malleability, co-production has proven to be a powerful analytical tool for studying the formation of scientific knowledge. ${ }^{16}$ In this paper, I use co-production to describe two related processes: first, to illustrate how Secrets were part of a constellation of cultural products that represented the natural world, and were therefore ingrained in a

11 Bowler, op. cit. (8), pp. 213-14.

12 Timothy Boon, Films of Fact: A History of Science in Documentary Films and Television, London: Wallflower, 2008; Oliver Gaycken, Devices of Curiosity, Oxford: Oxford University Press, 2015; Luke McKernan, Charles Urban: Pioneering the Non-fiction Film in Britain and America, 1897-1925, Exeter: University of Exeter Press, 2015; Michael Chanan, The Dream That Kicks: The Prehistory and Early Years of Cinema in Britain, London: Routledge, 1980; Scott Curtis, The Shape of Spectatorship: Art, Science and Early Cinema in Germany, New York: Columbia University Press, 2015. On natural history television see Gail Davies, 'Science, observation and entertainment: competing visions of postwar British natural history television 1946-1967', Ecumene (2000) 7, pp. 432-60; Jean-Baptiste Gouyon, BBC Wildlife Documentaries in the Age of Attenborough, Cham: Palgrave, 2019. See also Loraine Daston and Peter Galison, Objectivity, New York: Zone Books, 2010; Iwan Rhys Morus, 'Seeing and believing science', Isis (2006) 97, pp. 101-10.

13 Derek Bousé, Wildlife Films, Philadelphia: University of Pennsylvania Press, 2000; Greg Mitman, Reel Nature: America's Romance with Wildlife on Film, Cambridge, MA: Harvard University Press, 1999.

14 Hannah Landecker, 'Microcinematography and the history of science and film', Isis (2006) 97, pp. 121-32.

15 Jeffrey Richards, The Age of the Dream Palace: Cinema and Society in 1930s Britain, London: Routledge, 1984, p. 11.

16 Sheila Jasanoff, States of Knowledge: The Co-production of Science and the Social Order, London: Routledge, 2004, pp. 13-45; Peter Mandler, 'Good reading for the million: the "paperback revolution" and the co-production of academic knowledge in mid twentieth-century Britain and America', Past \& Present (2019) 244, pp. 235-69. 
wider 'inter-medial' public culture of natural history. ${ }^{17}$ Second, I use co-production to examine how the Secrets films, and the types of science they communicated, were shaped by a range of actors, from 'expert' advisers and film producers, to cinema owners, teachers, audiences and even plants and animals themselves. Cinema's inherently collaborative methods, as well as its large audiences, present an ideal case study for co-production. Because co-production foregrounds knowledge as constitutive of modern democracy and citizenship, it is also an especially suitable lens to study the scientific culture of interwar Britain. ${ }^{18}$ Historical interpretations of this period argue that mass media played a pivotal role in what D.L. Lemahieu calls an 'emerging common culture' defined by new ways of consuming information. ${ }^{19}$ Communications technologies like film and radio were viewed as having a responsibility to disseminate knowledge, famously exercised in the BBC's 'public service broadcasting'. ${ }^{20}$ Moreover, the life sciences, and their potential applications in topics of contemporary political concern like heredity and agriculture, occupied a prominent place in interwar cultural discourse. ${ }^{21}$ Non-fiction cinema, therefore, offers an especially interesting case study in the penetration of the life sciences, by means of mass media, in interwar British culture.

This article is divided into three parts. The first introduces Secrets and their principal themes, linking them to contemporary trends in mass interwar scientific culture, from printed matter to zoos. The second part assesses the role of the individuals behind the series, including academic scientists, nature photographers, producers and teachers. As professional 'advisers' became more influential, the pedagogical nature of the series took on more importance. In articulating their views on the place of film in scientific and wider culture, the Secrets producers coined a new term: 'ciné-biology' was both a cinematic style and a scientific method. Crucially, ciné-biology required the active participation of audiences: the third and final part draws on the rich evidence of interwar cinema experiments to examine what they tell us about the place of audiences - real and imagined -in co-producing these films. Secrets were an indispensable part of the culture of public science in interwar Britain: they forged a special place for the life sciences in popular culture and made the case for film as a tool not only for disseminating, but also for producing, scientific knowledge.

17 Sian Nicholas, 'Media history or media histories? Re-addressing the history of the mass media in interwar Britain', Media History (2012) 18, pp. 379-94. See also Bernhard Rieger, Technology and the Culture of Modernity in Britain and Germany 1890-1945, Cambridge: Cambridge University Press, 2009.

18 Sheila Jasanoff, Designs on Nature: Science and Democracy in Europe and the United States, Princeton, NJ: Princeton University Press, 2007.

19 D.L. LeMahieu, A Culture for Democracy: Mass Communication and the Cultivated Mind in Britain between the Wars, Oxford: Oxford University Press, 1988, p. 4.

20 Paddy Scannell and David Cardiff, A Social History of British Broadcasting, vol. 1: 1922-1939, Serving the Nation, Oxford: Basil Blackwell, 1991, p. 13. See also Laura Carter, 'Higher education and the pedagogies of communicating elite knowledge in 1970s Britain', in Joaquim Moreno (ed.), The University Is Now on Air: Broadcasting Modern Architecture, Montreal: CCA, 2018, pp. 137-47.

21 Roger Smith, 'Biology and values in interwar Britain: C.S. Sherrington, Julian Huxley and the vision of progress', Past and Present (2003) 178, pp. 210-42. 


\section{Films}

Secrets were generally about ten minutes long. The most common format was the 'lifecycle' film of a single plant or animal's growth, life and reproduction. Others were 'compilation' films, where specific processes such as pollination, courtship or animal motion were illustrated by collating footage from different species. These were often locationspecific, exploring the fauna and/or flora of a place, as in Springtime in the Scillies (1932). Fifty-one Secrets dealt with ornithology, although this excludes many 'compilation' films featuring birds. Shot in the open, they included The Sparrow-Hawk (1922) and The Merlin (1930). Forty-five films showed insects, with titles like The Lair of the Spider (1922) and Looper Caterpillars (1935). Moths and butterflies were a common subject, with a total of ten films, including The Comma Butterfly (1922). A further thirty-nine Secrets focused on plants, mostly produced after Percy Smith joined the team in 1926. Moreover, films like Magic Myxies (1931) offered spellbinding images of the growth and reproduction of fungi. Forty films showed aquatic subjects, including crabs, starfish and frogs, among other marine and freshwater animals (Figure 1). This wide range of subjects is reflective of the contemporary culture of amateur natural history to which the Secrets films belonged.

All Secrets relied on a heavy dose of anthropomorphism, light humour and drama. In 1929 , sound versions replaced the earlier written captions. They were voiced first by Victor Peers, and later by E.V.H. Emmett, whose upper-middle-class voices embodied the characteristic newsreel sound of the era: quickly spoken but sharp, clear and rich, delivered with the brio of a music-hall host. This tone was not always popular, and reviewers criticized its 'facetiousness'. ${ }^{22}$ Light-entertainment music was composed especially by W.E. Hodgson. Narration frequently drew comparisons with work or family life: in The Tough 'Un (1938), a film about dandelions, a bee 'doesn't mind her old man coming back with his feet covered in pollen, as long as he takes off his boots in the kitchen'. Referring to everyday life experiences, which was a common trope of popular natural histories, became the principal way in which natural historical knowledge was made vernacular in these films. ${ }^{23}$ According to Mary Field, the 'golden rule' of nature filmmaking was to 'always start with the familiar, and never let members of your audience feel that they have strayed from the paths of their ordinary experience'. ${ }^{24}$

The Secrets films were made at a time when outdoor leisure and rural life were becoming entangled with modernity. ${ }^{25}$ Rambling, camping, cycling, hostelling, gardening and other outdoor pursuits enjoyed widespread popularity. Cultural products like Secrets tapped into this current, recasting natural history in a new and modern light. Several ornithological Secrets from the 1930s attest to this. Special Messengers (1930), for example, looked at the breeding of racing pigeons in urban areas. Urban Visitors

22 The Times, 21 December 1939, p. 6; Educational Film Review and Industrial Cinematography (1935) 1, p. 93.

23 Bowler, op. cit. (8), p. 52.

24 Radio Times, 22 January 1937, p. 5.

25 David Matless, Landscape and Englishness, London: Reaktion Books, 2001; Jon Agar and Jacob Ward (eds.), Histories of Technology, the Environment and Modern Britain, London: UCL Press, 2018. 


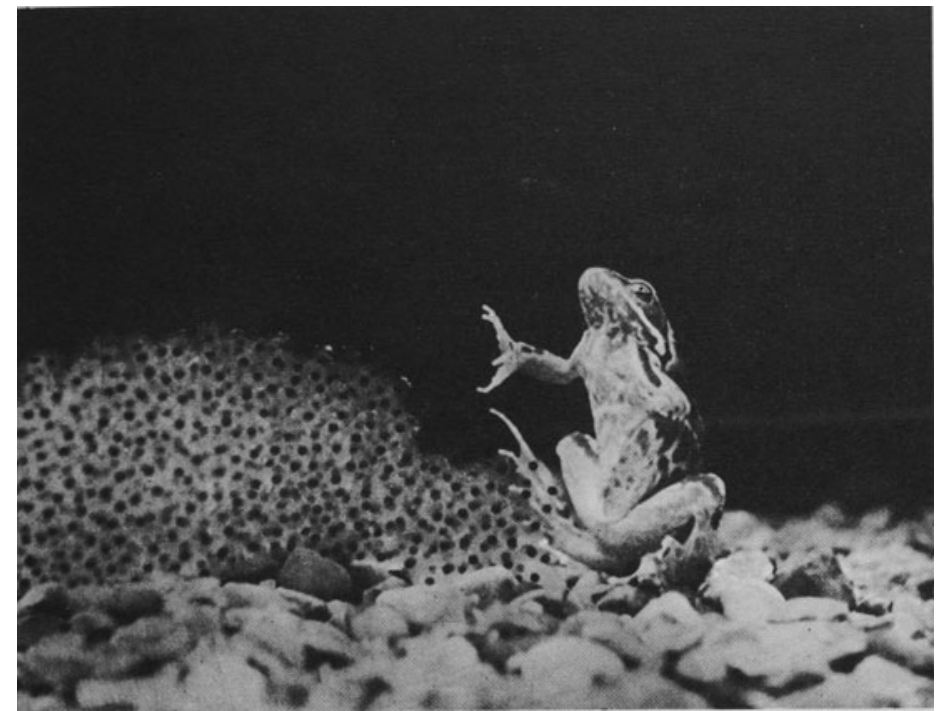

Figure 1. Mary Field and Percy Smith, Secrets of Nature, London: Faber \& Faber, 1934, p. 65.

(1936) followed the migration of the black-headed gull from the northern coasts of England to the London docks, where 'the roar of the traffic is swollen and sharpened by the shrill notes of the London Visitors'. In an intriguing formulation of urban ecology, the gulls were described as 'part of the pattern of a great city'. A film about pigeons, Living in London (1938), and another about sparrows, Percy Cockney (1938), also dealt with London's birdlife. Whether it was pigeons, crabs, snails, owls or fungi, Secrets mostly depicted species which were recognizable to their imagined urban audiences, but portrayed them in surprising or unconventional ways. This led one journalist to observe that the 'cinematograph has ... contributed more than any other single factor to the introduction of the man-in-the-street to the more intimate secrets of nature life'. ${ }^{26}$

The Secrets films departed from early twentieth-century wildlife film conventions, which centred on dangerous encounters with wild animals. ${ }^{27}$ They offered a tamer, more domesticated vision of the (mostly English) countryside. However, Secrets also made the London Zoo their stage. Dinner Time at the Zoo (1923) showed the feeding habits of different animals, while Round the Empire at the Zoo (1926) featured animals from British imperial territories. As a form of 'rational recreation', zoos enjoyed a high degree of popularity in interwar Britain and became firmly associated with children's entertainment. ${ }^{28}$ Films tried to capture the atmosphere of the average

26 Exeter and Plymouth Gazette, 13 February 1932, p. 5.

27 Mitman, op. cit. (13), pp. 31-5.

28 Andrew Flack, The Wild Within: Histories of a Landmark British Zoo, Charlottesville: University of Virginia Press, 2018, p. 18. See also Peter Bailey, Leisure and Class in Victorian England: Rational Recreation and the Contest for Control, 1830-1885, London: Routledge and Kegan Paul, 1978. 
zoo visit and capitalized on the existing popularity of individual animals. Like a visit to the zoo, Secrets were a family affair which sought cross-generational appeal. But films could achieve two things which were out of reach for the zoo: first, they could reach a wider audience, including people who lived too far-or were too poor-to visit in person. Second, producers could build powerful stories around zoo animals through montage and scripts; films dramatized the lives of captive animals and portrayed them only at their most 'active'. ${ }^{29}$

Interwar London Zoo guidebooks were filled with advertisements for cameras and film rolls, a reminder of how closely the zoo experience was tied to photography. Secrets complemented popular children's cartoons, such as the Daily Mirror's 'Pip, Squeak and Wilfred', and were the cinematic counterparts to David Seth-Smith's Zoo Man, one of the most popular features of the BBC's Children's Hour. ${ }^{30}$ These crossovers are worth underlining; without them we miss an important aspect of the media landscape of interwar Britain. Aside from conducting innumerable radio and newspaper interviews, often lavishly illustrated with stills and 'behind-the-scenes' images, Mary Field and Percy Smith collaborated on several companion books, including Secrets of Nature (1934). These books expected viewers to inquire further about the subjects they saw on the screen: aside from explaining how the films were made, they behaved as popular natural histories in their own right. In this way, natural history films belonged to an assemblage of mass cultural products in the wider natural history ecosystem, which also included serialized books like J. Arthur Thomson's New Natural History, natural history museums, and newspaper science columns.

Although many Secrets had more in common with Victorian natural history than with twentieth-century zoology, the series also portrayed more up-to-date practices. Conservation, for instance, was a matter of national importance in the interwar period. ${ }^{31}$ The implications of ecological science for habitat conservation began to be articulated during these years, with Charles Elton's Animal Ecology appearing in 1927. In field ecology, perhaps more than in other life sciences, photography became embedded in scientific practice. ${ }^{32}$ Beyond raising awareness, films could be records: in 1927, London's Natural History Museum accepted a copy of the US wildlife film Chang on the ground that 'it will be desirable to acquire films recording animals

29 On film and zoos see Jonathan Burt, Animals in Film, London: Reaktion Books, 2002; John Berger, 'Why look at animals', in Berger, About Looking, London: Penguin, 1980, pp. 1-26; Michael Lawrence and Karen Lury, The Zoo and Screen Media: Images of Exhibition and Encounter, London: Palgrave Macmillan, 2016; Akira Mizuta Lippit, Electric Animal: Toward a Rhetoric of Wildlife, Minneapolis: University of Minnesota Press, 2000.

30 Simon Flynn, 'Out with Romany: simulating the natural in BBC Radio's Children's Hour 1932-1943', in Karín Lesnik-Oberstein (ed.), Children in Culture, Revisited: Further Approaches to Childhood, London: Palgrave Macmillan, 2011, pp. 186-207.

31 John Sheail, An Environmental History of Twentieth-Century Britain, Basingstoke: Palgrave, 2003, pp. $103-45$.

32 Damien Hughes, 'Natural visions: photography and ecological knowledge, 1895-1939', PhD thesis, De Montfort University, 2016; Robert E. Kohler, Landscapes and Labscapes: Exploring the Lab-Field Border in Biology, Chicago: The University of Chicago Press, 2002, pp. 124-7. 


\section{Max Long}

which are scarce and likely to be exterminated'. ${ }^{33}$ From the 1930 s, Secrets increasingly addressed the interdependence of plant and animal life: 'compilation' films like Life in the Balance (1936) and Tree Triumphant (1944) encouraged viewers to reflect on the 'balance' of life. The Warblers (1934) ended with a warning that the birds helped 'to preserve the leafy loveliness of our English countryside. We should therefore protect the warblers'. The marine-biological stations at Plymouth and Millport, both key sites for British ecology, also collaborated with several Secrets. ${ }^{34}$ These films, therefore, reflected what Robert E. Kohler calls the 'lab-field border', a distinct cultural space opened up by 'new naturalists' at the turn of the century, whose broad vision of natural history and biology combined field studies with lab-based experimentation. ${ }^{35}$ Moreover, films like War in the Trees (1931), about the Sirex woodwasp in Australia, chimed with interwar enthusiasm for British imperial research in applied science. ${ }^{36}$ Many of the same individuals who made Secrets would later work on agricultural films for institutions like the British Council, promoting empire and Commonwealth interests.

Reproduction was a pervasive concern in Secrets, a theme which persists in nature documentaries today. ${ }^{37}$ Life cycles of moths and butterflies, for instance, produced impressive moving images. Plant pollination was a favourite topic: Floral Co-operative Societies (1927) contrasted the reproduction of dandelions, daisies, cornflowers, carline thistles and everlastings. Beyond lessons about sexual processes in plants and animals, natural history was used to teach children about human reproduction, and this partly explains the theme's dominance. ${ }^{38}$ In the words of one teacher, 'Nature Study is one of the best ways for the child to come to a knowledge of birth'. ${ }^{39}$ Oliver Gaycken argues that film's ability to manipulate time made it especially suitable for visual demonstrations of evolution. ${ }^{40}$ The prominence of evolution and Mendelian inheritance in interwar eugenicist discourses therefore provides a further explanation for the emphasis on reproduction in Secrets films. This is underlined by the fact that the same production team was behind the infamous Heredity in Man (1937). A third explanation lies in anxieties surrounding Hollywood films. For many, Secrets offered a morally uplifting antidote to Hollywood's sexual depravity: in 1927, George Bernard Shaw introduced a

33 Natural History Museum, London, DF1004-815, Herbert Smith to Arundell Esdaile, 13 September 1927.

34 David Elliston Allen, The Naturalist in Britain: A Social History, Princeton, NJ: Princeton University Press, 1994, p. 212. See also Sheail, op. cit. (31), p. 125.

35 Kohler, op. cit. (32), pp. 23-59.

36 Robert Bud, 'Modernity and the ambivalent significance of applied science: motors, wireless, telephones and poison gas', in Robert Bud, Paul Greenhalgh, Frank James and Morag Shiach (eds.), Being Modern: The Cultural Impact of Science in the Early Twentieth Century, London: UCL Press, 2018, pp. 95-129.

37 Bousé, op. cit. (13), pp. 152-61; Laura McMahon and Michael Lawrence (eds.), Animal Life and the Moving Image, London: Bloomsbury Academic, 2015. See also Jesse Olszynko-Gryn and Patrick Ellis, ““A machine for recreating life": an introduction to reproduction on film', BJHS (2017) 50, pp. 383-409.

38 Jennifer Peterson, 'Glimpses of animal life: nature films and the emergence of classroom cinema in the 1920s', in Dan Streible, Marsha Orgeron and Devin Orgeron (eds.), Learning with the Lights Off: Educational Film in the United States, Oxford: Oxford University Press, 2012, pp. 145-67.

39 Irene Broomhall, 'The teaching of nature study', School Nature Study (1936) 31, pp. 13-15.

40 Oliver Gaycken, 'Early cinema and evolution', in Bernard Lightman and Bennett Zon (eds.), Evolution and Victorian Culture, Cambridge: Cambridge University Press, 2014, pp. 94-120. 
Secrets screening by railing against the obsession with sex in mainstream films. One journalist was quick to point out the paradox that, in most Secrets, 'the importance of sex is shown to be paramount'. ${ }^{41}$ Some Secrets even exploited the opportunity to attract viewers expecting something more racy: The Mystery of Marriage (1931) contrasted courtship in humans, animals and fungi, and was advertised as 'children not admitted'. ${ }^{42}$ A 1935 Punch cartoon parodied the sexual undertones of nature films: a man approaches a cinema advertising several suggestive films to enquire if 'this is the cinema that's showing "The Life Story of the Newt?"'.43 Natural history films may not have had the sex appeal of Hollywood stars, but a significant part of their entertainment value did rely on playfully evoking the cinema's - and natural history's - associations with sex.

The Secrets films, moreover, raised compelling questions about non-human agency. Beyond the frequent anthropomorphism exhibited in the films, producers frequently referred to animals as 'actors' over whom they had 'the minimum of control'. ${ }^{44}$ Field wrote that animals 'are really only like human actors', adding that 'natural subjects are sensitive to atmosphere and, if you are on edge, they become nervy too'. ${ }^{45}$ They also experimented with animal points of view: U-Boat in the Pond (1942) used multiple tiny lenses to imitate - however inaccurately - the dityscus beetle's eyes. Plants, too, were antropomorphized. Time lapse and magnification appeared to endow plants with animal-like movement and even thought. ${ }^{46}$ One observer noted that the films portrayed the 'dynamic quality' of plants, making film a 'truer representation of reality than any other medium'. ${ }^{47}$ A catalogue for The Life of a Plant (1926) explained that the movements of a garden nasturtium could be observed at 'a speed two hundred thousand times quicker' than normal (Figure 2). ${ }^{48}$ Watching this film, a reviewer commented that 'you find it difficult to believe, as you view the picture, that the life of a plant is not as sentient as your own'. ${ }^{49}$ Down Under (1930), moreover, told viewers that a root's tip 'acts like a brain'. Smith frequently reflected that speed and magnification posed unresolved questions about non-human life. Speaking of the 'criminal' dodder in The Strangler (1930), he confided, 'I was astonished to observe the uncanny, human-like way in which he ensnared his victims.' 50 Commentators have characterized this technological anthropomorphism as a form of vitalism, and Secrets' collaboration

41 Daily News, 9 November 1927. This and subsequent newspaper references where page numberings are absent are from Percy Smith's scrapbook at the National Science and Media Museum, Bradford, Charles Urban Collection, URB 8/2.

42 Nottingham Journal, 18 September 1931, p. 4.

43 William Ridgewell, Punch (1935) 188, p. 253.

44 Field and Smith, op. cit. (3), p. 71.

45 Mary Field, 'Making nature films', Sight and Sound (1932) 1, pp. 70-1.

46 Oliver Gaycken " "The swarming of life": moving images, education, and views through the microscope', Science in Context (2011) 24, pp. 361-80; Edward Juler, 'The key to a hidden world: photomicrography and close-up nature photography in interwar Britain', History of Photography (2012) 36, pp. 87-98.

47 W.M. Warden, 'Films in nature study and biology', School Nature Study (1939) 34, p. 50.

48 BFI National Archive, Brunel Box 114, Item 3, 'Catalogue of films for non-theatrical exhibition', n.d.

49 Sunday Express, 18 September 1927.

50 Film Weekly, 2 June 1933. 


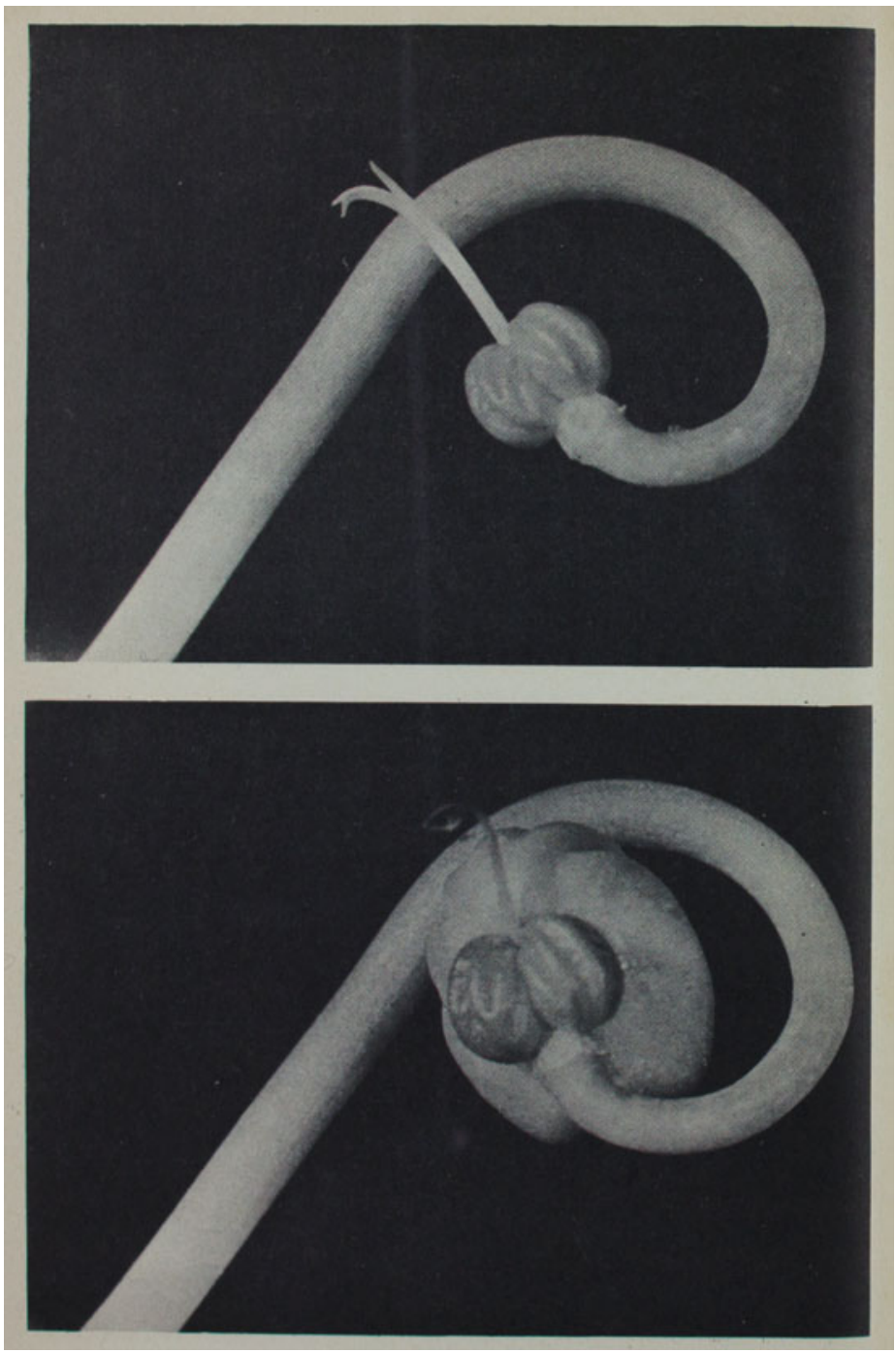

Figure 2. Stills from a Secrets film, showing a nasturtium seed developing. Field and Smith, op. cit., p. 165.

with E.J. Salisbury and J. Arthur Thomson lends weight to this. ${ }^{51}$ No doubt stoking speculation about animal emotions or plant sentience was seen as good publicity for Secrets. But even with a healthy dose of cynicism about producers' intentions, we can see that these films presented viewers with new forms of knowledge that challenged

51 Caroline Hovanec, 'Another nature speaks to the camera: natural history and film theory', Modernism/ Modernity (2019) 26, pp. 243-65; Christina Alt, Virginia Woolf and the Study of Nature, Cambridge: Cambridge University Press, 2010, pp. 1-33. See also Teresa Castro, 'The mediated plant', e-flux journal (September 2019) 102, at www.e-flux.com/journal/102/283819/the-mediated-plant, accessed 26 May 2020. 
their existing assumptions. Moreover, because the behaviours, movements and responses of natural subjects were so central to the narrative of the films and their publicity - and were treated seriously by filmmakers - they may themselves be considered coproducers of the films. ${ }^{52}$ The next section of this paper looks more closely at the individuals involved in making Secrets, establishing further how knowledge was co-produced in the series.

\section{Ciné-biologists}

Showcasing cutting-edge technology was at the heart of the Secrets style. In 1928, BIF opened the first dedicated sound studios in Britain. ${ }^{53}$ In 1929 the Secrets team recorded their first talkie, Peas and Cues, and ten years later Bruce Woolfe unveiled the first Secrets shot in colour. ${ }^{54}$ The Secrets team coined a new term, 'ciné-biology', to describe their style. It first appeared in a co-authored book by J.V. Durden, Mary Field and Percy Smith called Ciné-Biology (1941), although the term was not properly defined until the book's sequel, See How They Grow (1952). ${ }^{55}$ Both were released in Penguin's Pelican series, which published titles written by specialists for general audiences. ${ }^{56} \mathrm{By}$ no means the first attempt to theorize the relationship between cinema and science, this was perhaps the clearest and the most public. ${ }^{57}$ Ciné-biology was the 'the study of life through the medium of the cinema': it harnessed film and its associated technologies, including time-lapse and microcinematography, to observe the natural world. ${ }^{58}$ The "revealing "eye" of the microscope and the "analytical "brain" of the camera were described as active observers: by portraying the aliveness of the world, technology itself came to life. ${ }^{59}$ Although the term was coined in reference to laboratory films, cinébiology aptly describes the Secrets project in its entirety. Capturing and manipulating movement was ciné-biology's most critical characteristic: 'Movement, despite the advent and firm establishment of sound films, is the essence of the cinema ... And, in the cinema, we have the ideal medium for the study of life. ${ }^{60}$ Ciné-biology necessarily foregrounded natural movements and processes over morphology, something which chimed with many scientists' desire to establish a 'general' biology combining natural history with lab-based experimentation. ${ }^{61}$ Controversially, ciné-biology prioritized form over content: scientific accuracy could be sacrificed by appealing to viewers'

52 Donna Haraway, Primate Visions, New York: Routledge, 1989; Cary Wolfe (ed.), Zoontologies: The Question of the Animal, Minneapolis: University of Minnesota Press, 2003; Amanda Rees, 'Animal agents? Historiography, theory and the history of science in the Anthropocene', BJHS Themes (2017) 2, pp. 1-10.

53 Kinematograph Yearbook, London: Kinematograph Publications, 1929, p. 24.

54 Field and Smith, op. cit. (3), pp. 234-5; Kinematograph Weekly, 20 July 1939.

55 Mary Field, Percy Smith and J.V. Durden, Ciné-Biology, London: Pelican, 1941, p. 9.

56 Mandler, op. cit. (16).

57 Hannah Landecker, 'Cellular features: microcinematography and film theory', Critical Enquiry (2006) 31, pp. 903-37.

58 Mary Field, Percy Smith and J.V. Durden, See How They Grow, London: Pelican, 1952, p. ix.

59 Field, Smith and Durden, op. cit. (58) p. 52.

60 Field, Smith and Durden, op. cit. (58), pp. viii-ix, original emphasis.

61 Kohler, op. cit. (32), pp. 252-92. 
imaginations with anthropomorphic quips or by referring to plants' 'brains', as long as audiences left the cinema having gained new insights into biological processes.

Ciné-biology was partly about status and expertise. Durden was 'amazed and disquieted' at the fact that 'the film is not more widely recognised and employed, as a most valuable tool and method of record in the hands of the scientific fraternity'. ${ }^{62}$ Coining the term was an attempt to simultaneously bolster Durden and others' professional credentials while portraying their work as scientifically valuable. It treated film not merely as a medium for communicating scientific knowledge, but as a discipline of its own, complete with tools, practices and methods. Despite its focus on expertise, however, ciné-biology was an inclusive rather than an exclusive concept: its results were 'for all to see', and the public were all 'would-be ciné-biologists and researchers with the camera'. ${ }^{63}$ Ciné-biology also made science more appealing, adding 'a spice of liveliness to the dull science of botany'. ${ }^{64}$ In keeping with the spirit of the Pelican series, readers were encouraged to emulate at home what they saw in the cinema. These characteristics of ciné-biology - the emphasis on specific film techniques, the assertions about the medium's status as a scientific tool, and the ambition of engaging and involving a mass audience-were the principal pillars that defined the Secrets series. Moreover, by recognizing the interlacing roles of filmmakers, experts, technologies and the wider public in making nature films, ciné-biology was an implicit acknowledgement of how scientific knowledge was co-produced in Secrets films.

Who exactly were the ciné-biologists? The earliest Secrets were collaborations between naturalist photographers and film producers. Smith and Field believed that the personalities of individual cameramen-they were all men-became 'indelibly printed' on their films. Edgar Chance was a 'scientist', H.A. Gilbert a 'sportsman', and Walter Higham an 'artist', while Charles Head was 'an eighteenth-century diarist' and Oliver Pike was like 'the better type of journalist'. ${ }^{65}$ Most of these individuals were dedicated ornithologists but were considered 'amateurs' because of their lack of qualifications. They all published popular ornithology books. Chance's film The Cuckoo's Secret (1922) was touted as the first visual record of the common cuckoo laying its eggs. Pike was a celebrated bird photographer known for his pioneering films In Birdland (1907) and St. Kilda, Its People and Birds (1908). These photographers were products of the enthusiastic adoption of photography by birdwatchers around the turn of the century, replacing rifles with lenses. Their expertise, as embodied by their contemporary Cherry Kearton, relied on establishing a sense of intimacy with their subjects, and the ability to build 'hides' from which to observe them. ${ }^{66}$ Occasionally, early Secrets advertised the collaboration of notable scientists like Peter Chalmers Mitchell and J. Arthur Thomson, but these were sporadic. Other early

62 Durden to Dr. A. Pijper, n.d. [1944], British Film Institute, London (subsequently BFI), J.V. Durden Collection (subsequently JVD), ITM-17098, Film Productions 3/3.

63 Field, Smith and Durden, op. cit. (58), pp. ix, 40.

64 Field, Smith and Durden, op. cit. (58), p. ix.

65 Field and Smith, op. cit. (3), p. 26.

66 Jean-Baptiste Gouyon, 'From Kearton to Attenborough: fashioning the telenaturalist's identity', History of Science (2011) 49, pp. 25-60; Allen, op. cit. (34), p. 230. 
collaborators, like W.P. Pycraft, an assistant at the British Museum (Natural History) and popular-science author, clearly treated the films as an opportunity to boost their visibility. By the 1930s, however, the importance of the lonesome nature photographer began to wane, as the influence of producers and scientific advisers increased. ${ }^{67}$ By 1941, Field argued that Secrets 'brought together skilled naturalists, and cameramen who hardly knew a sparrow from a chicken'. ${ }^{6}$

Margaret Thomson's oral history sheds some light on the different roles played by producers, advisers and cameramen. In 1937 Thomson, a zoology graduate from New Zealand, made six ecology films for GBI. Thomson recalls that Percy Smith was a 'wizard', adding that 'any of the things that I needed to have done I'd only got to have to say to him ... I want an earthworm, eating leaves and distributing them into the soil, and he'd do it'. ${ }^{69}$ Where previously the content of films had been determined by 'freelance' cameramen's footage, by the 1930s the authority was centralized in the hands of producers and advisers. However, directors' requests could not always be fulfilled, and in these instances the cameramen's field knowledge came once more to the fore:

sometimes they'd say we haven't been able to find such and such a bird in the habitat you are talking about, but we've got a dipper in the same habitat, would that be any use to you, so I'd go back to my advisers and say would this be any good, and you know, we'd have to compromise now and then. ${ }^{70}$

The symbolic role of these advisers is captured in a 1937 photograph showing the botanist E.J. Salisbury and the physiologist Winnifred Cullis, two prominent public-facing scientists who collaborated with GBI, alongside Field and Bruce Woolfe (Figure 3). The image shows the four subjects in a spacious studio, with the two scientists on the left proffering an open book to the producers. Bruce Woolfe and Field - the latter clinging authoritatively to a studio lamp - point at the book, as though assenting to the scientists' advice. This highly orchestrated image illustrates the shared authority between producers and consulting scientists that Secrets aimed to transmit.

On at least one occasion the Secrets team were subject to censorship by the British Board of Film Censors, who ruled in 1936 that The Frog was 'too intimate, in detail, for general exhibition to mixed audiences including children' ${ }^{71}$ These films tested the limits of an inflexible regulatory system that assumed firm distinctions between science, education and entertainment. Censorship was not only moral: the 1925 Finance Act failed to distinguish between commercial and non-commercial films, making it hard for scientists to source foreign films without paying costly import duties. An exemption in 1928 required the Royal Society to certify individual films as 'solely an illustration of scientific investigation'. ${ }^{72}$ The 1927 Cinematograph

67 On scientific advisers in Hollywood see David Kirby, Lab Coats in Hollywood: Science, Scientists, and Cinema, Boston: MIT Press, 2010.

68 Field, op. cit. (3), p. 44.

69 Imperial War Museum, London, 13446 Margaret Thomson (Oral History), 1993.

70 Thomson, op. cit. (69).

71 BFI, London Scientific Film Society Collection, Item 8 (a-g), 'Fourth performance, Sunday March 5th 1939'.

72 Bodleian Library, Oxford, Dep. BAAS 98, H.H. Dale to J. L. Myres, 24 December 1928. 


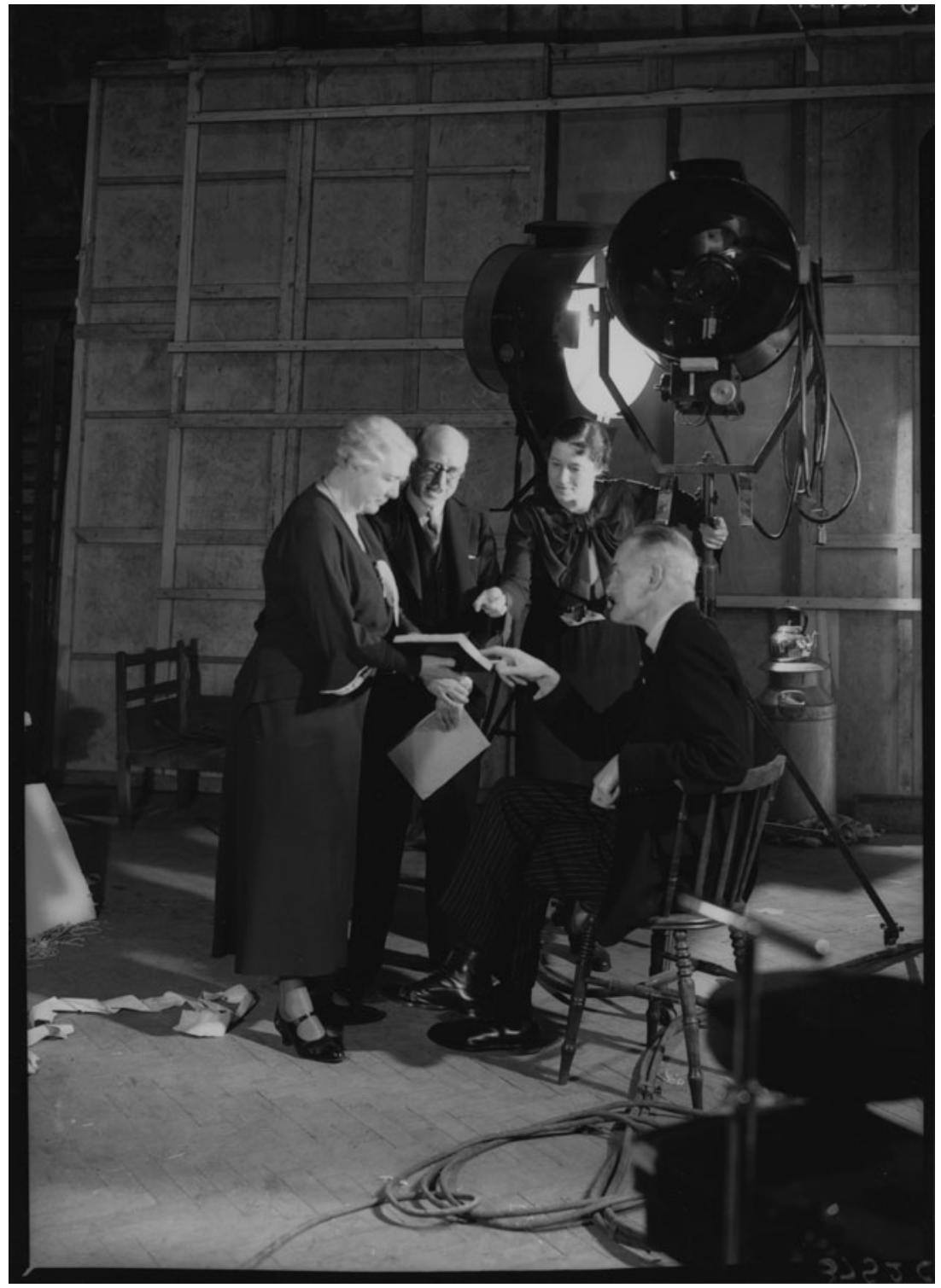

Figure 3. Harry Bruce Woolfe, Winifred Clara Cullis, Mary Field and Sir Edward James Salisbury, by Howard Coster. Half-plate film negative, 1937. National Portrait Gallery, London, NPG x23985. ( National Portrait Gallery, London.

Films Act, which introduced a 'quota' for British films to bolster the industry, excluded educational and scientific shorts until a new Act was passed in 1938. This disincentivized the exhibition in cinemas of non-commercial films and perhaps 
encouraged the Secrets producers to make some of their films more 'entertaining' and therefore marketable. ${ }^{73}$

With the move to GBI in 1934, the Secrets team formalized the production of separate entertainment and educational films by embarking on a series of biology teaching films. According to Field, these were 'often confused' for Secrets, an understandable error given the significant crossover between the two. Already with Secrets of Nature two versions of the same film-one theatrical and one instructional-had occasionally been issued. Many were released on $16 \mathrm{~mm}$ stock, which had a lower fire risk and became the standard for educational films. The GBI biology films were aimed at a range of classroom audiences, from primary school to university, and were mostly laboratory-based technical films on subjects like The Amoeba (1934) or The Sea Urchin (1936). However, traditional natural history topics like Looper Caterpillars (1935) and ecological ones like Heathlands (1938) were also produced. GBI's biology films were supervised by Julian Huxley and H.R. Hewer and edited by J.V. Durden: Durden and Hewer often also appeared in Secrets of Life credits. Although Huxley was not credited in the Secrets films, he was on friendly terms with Percy Smith, with one GBI employee observing, 'You should hear their backchat when they get together. It's an education in itself!'74 These films, therefore, were undoubtedly part of the same project as Secrets. Durden took a degree in biology and entomology at the Royal College of Science, later fashioning himself as 'a peculiar hybrid, a scientist turned film technician'. Despite coining the term 'ciné-biology', he declared himself a 'newcomer in this field'. ${ }^{75}$ Durden incorporated many of Percy Smith's techniques, but aimed to more fully integrate film studio and laboratory, anticipating Oxford Scientific Films' television work in the 1960s. ${ }^{76}$ Durden worked closely with Hewer, a zoologist at Imperial College who corrected his scripts and was an advocate of cinematography in the study of animal behaviour, including in his own research on seals. ${ }^{77}$

The nascent interest of professional scientists in the film medium is reflected in a 1935 report by Huxley, recommending the establishment of a film unit and 'specialised cinema' at the London Zoo. In Huxley's view, although popular films were a 'good advertisement for the Zoo', the private model of film production meant that specialists and institutions like the ZSL had little control over content. ${ }^{78}$ Earlier, Huxley had praised Secrets both for their general appeal and for their 'intrinsic scientific interest'. ${ }^{79}$ Given Huxley's well-documented enthusiasm for engaging members of the public in collecting scientific data, his involvement may be read as an attempt to harness film's visual

73 John Sedgwick, Popular Filmgoing in 1930s Britain: A Choice of Pleasures, Exeter: Exeter University Press, 2000, pp. 51-4.

74 Joan Woolcombe, 'Making nature “act”: secrets of life coaxed onto the screen', Windsor Magazine, November 1936, p. 788. Huxley collaborated on the film The Private Life of the Gannet, which received an Academy Award for best documentary in 1934.

75 BFI, JVD, ITM-17098, 'The technique of ciné-biology'; and Field, Smith and Durden, op. cit. (58).

76 Gouyon, op. cit. (12), pp. 179-204.

77 Imperial College, London, H.R. Hewer Collection, 165-72.

78 Zoological Society of London, secretary's reports and memoranda 1928-68, GB0814BBA, 'Memorandum on proposed natural history cinema at Regent's Park (1936)'.

79 Julian Huxley, 'Secrets of nature', Sight and Sound (1934) 3, p. 120. 
and sensual pleasure for this purpose. ${ }^{80}$ However, we must be careful not to overemphasize the influence of scientific advisers. The Secrets films enjoyed nearly a decade of popular success before they took any serious interest in the films, by which time Secrets had developed a distinct and enduring style of filmmaking. Its breadth of content, its combination of field and lab-based subjects and its mass appeal made ciné-biology an especially suitable genre for scientists like Huxley, who hoped to establish a 'general biology' which focused on processes and dynamic structures over practical instruction. ${ }^{81}$ Seen from this angle, the involvement of scientific consultants can be seen as an endorsement of the Secrets style - of ciné-biology - rather than an attempt to adapt the film medium to meet their own ends.

Collaborations between filmmakers and external experts were facilitated by the British Film Institute. The BFI was established in 1933 following the publication of The Film in National Life (1932), the final report of the Commission on Educational and Cultural Films, which recommended, 'The most expert work of the producer and technician must be linked with the professional knowledge of the specialist and the teacher. 82 Teachers were increasingly sought out as collaborators as the educational aspects of Secrets grew in importance. BIF and later GBI worked the London County Council to offer free screenings of films for schoolchildren. In addition to distributing films, Gaumont sold projecting equipment-mostly to schools-through Gaumont British Equipments (GBE): in this respect Secrets served as advertisements for the medium itself. Many teachers had high standards for scientific films, and their input shaped the practice of ciné-biology, with one teacher writing, 'Films in science must demonstrate that the ciné-camera is capable of being an instrument in research'. ${ }^{83}$ Several Secrets films from the early 1930s were edited 'by a sub-committee of the London Teachers' Association', and Secrets were also included in BBC Schools Broadcasting literature. Clotilde von Wyss, an instructor at London's Institute of Education who studied with J. Arthur Thomson, was an adviser on several Secrets and GBI films. Von Wyss was enthusiastic about new teaching technologies: she broadcast on the BBC and was a founder of the Nature Study Union. ${ }^{84}$ Madeline Munro, a senior lecturer in biology at Furzedown Training College for Teachers, also consulted on several GBI ecology films. Two teachers even published a textbook based on GBI's biology films. ${ }^{85}$ The advice of teachers like von Wyss and Munro was crucial in ensuring that Secrets films could be marketed simultaneously as entertainment and education, which became increasingly important in the wake of the 1927 Cinematograph Act.

80 Anne Secord, 'Botany on a plate: pleasure and the power of pictures in promoting early nineteenthcentury scientific knowledge', Isis (2002) 93, pp. 28-57; Helen Macdonald, “"What makes you a scientist is the way you look at things": ornithology and the observer 1930-1955', Studies in History and Philosophy of Science Part C (2002) 33, pp. 53-77.

81 Joe Cain, 'Julian Huxley, general biology and the London Zoo, 1935-1942', Notes and Records (2010) 64, pp. 359-78.

82 Benjamin Gott, The Film in National Life, London: G. Allen \& Unwin, 1932, p. 52.

83 W.H. George, The Cinema in School, London: Pitman, 1935, p. 93.

84 'Obituary notices', Nature (1938) 142, pp. 944-5.

85 A.M.S. Clark and G. Buckland Smith, Looking at Life: An Introduction to Biology, Letchworth: J.M. Dent, 1939. 
In Ciné-Biology, Durden, Field and Smith aimed to 'blend together into one narrative ... the critical accuracy of the scientist, the exuberant enthusiasm of the naturalist, and the anthropomorphic ideas of the layman'. ${ }^{86}$ But who did the blending? Although Field praised Bruce Woolfe's 'unifying supervision', the bulk of production was left to her. Mary Field began working on Secrets of Nature in 1926, and by 1929 was series editor. Her status is comparable to that of Mary Adams, who pioneered scientific broadcasting on the BBC around the same time. ${ }^{87}$ Field, who trained as a history teacher, began working for BIF as a historical consultant. ${ }^{88}$ In a 1936 radio broadcast with Percy Smith, she argued that nature films were 'awkward to serve up as popular entertainment'. Whilst Smith felt that gripping an audience's attention depended on the range of natural subjects on offer, Field saw things differently: 'Nature always does things the same way, but I'm expected to produce variety in nature films. ${ }^{\text {' } 9}$ Certainly, Smith's innovative techniques produced impressive and consistently entertaining images. But alone they do not explain the long-lasting appeal of Secrets. Field wove these images into sophisticated and entertaining stories, forging both the narrative and the visual grammar of ciné-biology. Her grasp of film as a mass medium, from scriptwriting to montage, was practically unsurpassed in the natural history genre: she even dedicated an entire book chapter to explaining the importance of synchronizing sound and image. ${ }^{90}$ Field, who understood that nature film production needed to be 'amazingly elastic', seized every opportunity to highlight this aspect of her work. ${ }^{91}$ During a studio visit in 1927, she showed her guests an unedited film. 'Few people realise', she said, 'that the photography of this type of film ... plays only a very secondary part to the editing'. ${ }^{92}$ Field's membership of the Royal Photographic Society and the Scientific Film Society, moreover, suggests that her role as a producer of both entertainment and scientific films was respected. She once remarked, 'It's extraordinary how watching animals and birds has developed my sense of observation and sharpened my eyes and ears.'93 The final section of this article will consider natural history filmmakers' attempts to prove that the eyes and ears of the public might also be sharpened through watching their films.

\section{Audiences}

Who watched Secrets, and what did they make of them? We know that the average interwar cinemagoer was 'young, working-class, urban and more often female than male',

86 Field, Smith and Durden, op. cit. (58), p. 9.

87 Allan Jones, 'Mary Adams and the producer's role in early BBC science broadcasts', Public Understanding of Science (2012) 21, pp. 968-83.

88 On women's professional identities during this period see Heidi Egginton and Zoë Thomas, Precarious Professionals, London: Institute for Historical Research, 2020.

89 BBC Written Archives Centre, Caversham, scripts files, Filming and Natural History, 'Filming plants: a discussion between Miss Mary Field and Mr. Percy Smith', 8 April 1935.

90 Field and Smith, op. cit. (3), pp. 209-37.

91 Field, op. cit. (3), p. 5.

92 The Bioscope, 7 July 1927, p. 38.

93 Palestine Post, 8 September 1939. 
but beyond this it is difficult to draw conclusions. ${ }^{94}$ Interwar surveys suggest that nature films were marginal to the cinema-going experience. Sidney Bernstein's 1937 survey of 160,000 individuals, which for the first time asked about shorts, saw 'Science' and 'Animal life' relegated to the bottom three rungs. ${ }^{95}$ There is no mention of the series in Mass Observation's 1937 Bolton Worktown study, although 7 per cent of respondents listed 'Nature and reality' as their top choice. ${ }^{96}$ Class certainly played a part: Field and Smith admitted that their films enjoyed 'a strong following in what are known in the cinema trade as "better-class halls". 97 Notwithstanding, evidence of Secrets' popularity abounds. In 1930, The Merlin broke a record for shorts by running for 312 consecutive performances at the Marble Arch Pavilion. ${ }^{98}$ The Secrets films were a global phenomenon: in 1930, they were dubbed and distributed to 'nearly a hundred French provincial halls'.99 Films were also recorded in German, Italian and Spanish, and exported to Belgium, Switzerland, Sweden, Poland and the United States. ${ }^{100}$ Durden saw his first ever Secrets in Cape Town; the films were shown in multiple British colonies and dominions, and were part of the late empire's adoption of mass-media technology as a tool to promote its economic interests. ${ }^{101}$

The Secrets films were produced at a time when the value and use of cinema were fiercely debated. Some sections of society viewed cinema as a dangerous vector of social disruption, and technologies like time lapse and magnification could be singled out for their capacity to mislead. A 1922 report, for example, warned of 'the serious danger of the children receiving false impressions of nature' through these technologies, an accusation that fits into longer narratives about scientific images' claims to truth. ${ }^{102}$ But more worrying to many was the potential affective influence of nature films. In 1934, the psychiatrist Emanuel Miller found 'the sight of uncurling tentacles and agonising writhings of insects emerging from cocoons ... eerie in the extreme', and warned that children could find 'the large effects of nature' and 'the small and the slow' to be 'frightening or terrifying'. ${ }^{103}$ A 1937 conference of Christian societies complained of 'horrific films', including one showing 'the head of a bee magnified several

94 Richards, op. cit. (15), p. 15. See also Ross McKibbin, Classes and Cultures: England 1918-1951, Oxford: Oxford University Press, 1998, pp. 420-56; Sedgwick, op. cit. (73), pp. 39-47.

95 University of Sussex, Mass Observation Archive, Topic Collections, Films 1937-48, 17/2/A: 'The Bernstein questionnaire 1937', p. 16.

96 Jeffrey Richards and Dorothy Sheridan, Mass Observation at the Movies, London: Routledge, 2016, p. 34.

97 Field and Smith, op. cit. (3), p. 21.

98 The Bioscope, 16 April 1930, p. 35.

99 The Bioscope, 5 November 1930, p. 32.

100 The Bioscope, 19 March 1930, p. 32; National Archives, Kew, Board of Trade, BT 55/4, 'Committee on Cinematograph Films, Tuesday 30th June 1936, evidence of Mr. Bruce Woolfe', p. 8; Daily News, 1 January 1931.

101 Durden, op. cit. (62); Lee Grieveson, Cinema and the Wealth of Nations, Oakland: University of California Press, 2018, esp. pp. 185-94.

102 Report on the Use and Value of the Cinematograph in Education, London: HM Stationery Office, 1924, p. 75; Daston and Galison, op. cit. (12), pp. 115-90.

103 Richard Ford, Children and the Cinema, London: G. Allen \& Unwin, p. 22. 
thousand times' ${ }^{104}$ Paradoxically, these critics and the ciné-biologists shared a belief in the power of cinema to affect viewers in significant - and often emotional - ways. Where some saw the cinema as a dangerous influence, others, like J. Arthur Thomson, viewed the medium as an opportunity to train viewers in observation: 'I feel sure that those things grip us most firmly that we see most clearly ... As opportunities for seeing increase, the habit of picturing will grow, and rebellion against obscurities will become more insistent.' 105 These debates closely match the dichotomy, identified by Scott Curtis in 1910s German cinema, between observation and spectatorship. ${ }^{106}$ Ciné-biology, as already noted, treated audiences as active participants or observers, rather than as passive spectators.

The Secrets producers were adept at gathering information about viewers and their reactions - and took their feedback seriously. For instance, after the commercial flop of Fear! (1924) they decided that 'the public definitely does not like snakes'. Also, 'Frogs, birds, and English mammals are more or less safe for box-office appeal; and so are homely vegetables.' ${ }^{107}$ How were they so confident in their knowledge of public taste? One answer is that Secrets were repeatedly used in reports and experiments into the impact of film on viewers, and its applications as part of the visual education movement. ${ }^{108}$ Dozens of these were conducted during the interwar period in Britain and the US. ${ }^{109}$ These experiments were aimed largely at children, whose agency in shaping their outcomes was not negligible. ${ }^{110}$ As some of the few British films aimed at young audiences, Secrets were a natural choice. Bruce Woolfe, a serial committee member and tireless promoter of his own films, sought out every opportunity for their inclusion in these experiments. ${ }^{111}$ Harnessing social science as an empirical method to test film's capacity

104 BFI, BBFC Verbatim Reports, 'Children and films. Minutes of proceedings of a conference held under the auspices of the Cinema Christian Council and the Public Morality Council', 16 February 1937.

105 Sight and Sound (1932) 1, pp. 4-5.

106 Curtis, op. cit. (12), pp. 90-141.

107 Field and Smith, op. cit. (3), p. 50.

108 Katie Day Good, 'Sight-seeing in school: visual technology, virtual experience, and world citizenship in American education, 1900-1930', Technology and Culture (2019) 60, pp. 98-131.

109 See Sarah J. Smith, Children, Cinema and Censorship: From Dracula to the Dead End Kids, London: I.B. Tauris, 2005; Julia Bohlman, 'Finding Scotland's cinema factor: from The Cinema in Education (1925) to The Film in the Classroom (1933)', Visual Culture in Britain (2019) 20, pp. 221-38. For the US see Gareth S. Jowett, Ian C. Jarvie and Kathryn H. Fuller, Children and the Movies: Media Influence and the Payne Fund Controversy, Cambridge: Cambridge University Press, 1996. On using audience studies as historical evidence see Christine Grandy, 'Cultural history's absent audience', Cultural and Social History (2019) 16, pp. 1-21. British scientists took an active interest in this research: Nature editor Richard Gregory headed the British Association's film committee, and the association's secretary, J.L. Myres, chaired the Committee on Educational and Cultural Films.

110 Smith, op. cit. (109), esp. pp. 105-40. In 1954 Field, later executive officer of the Children's Film Foundation, conducted a survey of children's reactions to films using infrared photography: Children and Films: A Study of Boys and Girls in the Cinema, Dunfermline: Carnegie UK Trust, 1954.

111 In addition to the cases documented here, Secrets were employed in experiments in Birmingham (1935), Leicestershire (1929) and St Pancras, London (1932-3). On the Birmingham experiment see Angelo van Gorp, " "Springing from a sense of wonder": classroom film and cultural learning in the 1930s', Paedagogica Historica (2017) 53, pp. 285-99. Julian Huxley used Secrets in a 1930 study of East African audiences (National Archives, Kew, Colonial Office, CO 323/1252/15). 


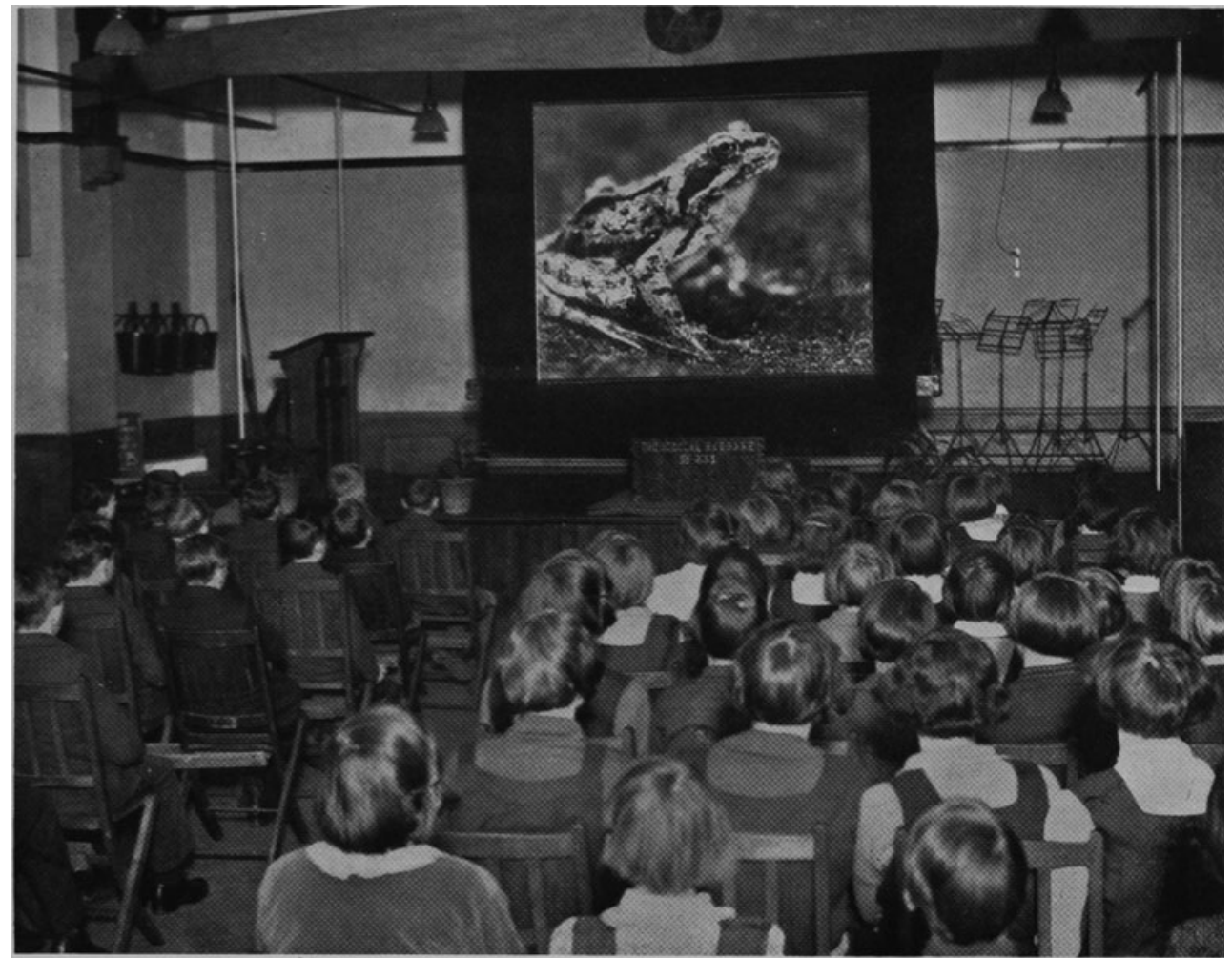

Figure 4. Children watching the Secrets of Nature film The Development of the Frog, as part of the Middlesex experiment in 1930. National Union of Teachers, Sound Films in Schools, London: The Schoolmaster, 1931, p. 25.

to evoke strong affective and emotional reactions, the Secrets producers bolstered their scientific credentials while simultaneously gathering evidence that supported their assumptions about audience tastes. Perhaps these sources tell us more about the sanguine outlook of film's advocates than about the experiences of natural history film audiences. However, by enquiring into cinema's effects, the authors of these studies made insightful observations specific to the natural history genre which fed directly into the production of ciné-biology.

The 'Middlesex experiment' (1930), for example, showed Secrets, among other films, to 3,602 children, in a study of the effectiveness of sound films in education. ${ }^{112}$ After seeing The Growth of Roots, teachers were 'unanimous in their approval of its nature and content', although several noted that the speeding up of images was confusing. One teacher commended the film's realism, saying it 'was such a graphic film, clear

112 The original film titles, all from 1930, were: The Frog, Down Under, The Aphis and The Flight Machine. 
and distinct, that it lived'. The Development of the Frog, the report stated, was 'much approved by teachers' because it showed 'essentials which a teacher could not describe'. Figure 4 shows a group of children dutifully paying close attention to the film. Its main weakness was comparing frogspawn to semolina pudding: 'children who had been struck by the form of the comparison stated that semolina pudding was frog's eggs'. The Aphis was described as 'calculated to inspire an intelligent interest'. The report observed that film could 'bring within the class-room a dynamic visual concept of life in its multitudinous manifestations'. ${ }^{113}$ A similar point had been made in an earlier report from Denton (Greater Manchester) in 1922, which stated that the 'real question' about natural history films hinged on 'whether they act as a powerful stimulus to the direct study of nature'. ${ }^{114}$ Given the Secrets films' ambitions of earning ciné-biology a place in the wider scheme of natural historical observation practices, these comments would have been considered especially valuable. Using experiments like the one conducted at Middlesex, therefore, the Secrets team killed two birds with one stone: they advertised their films as exemplary of the medium and received useful feedback which they could incorporate into future films.

Although Secrets were principally aimed at children, they were intended to interest adult audiences too. In 1932 the Workers' Educational Association (WEA) organized The New Learning, an investigation into rural film audiences in Devon (Figure 5). It featured several Secrets and was led by F.G. Thomas, who was curious to see if nature films had a significant impact on non-urban viewers. Thomas felt that, although the subject matter of nature films related more directly to rural lives, they could still offer new knowledge to country dwellers: 'although the countryman is acquainted with the externals of Nature, much is hidden from the most acute observer that can only be revealed by the microscope and camera in conjunction'. ${ }^{115}$ Thus, while the WEA tutors found the films 'unreal in that we did not know the flowers mentioned', in the case of the 'country people' the films were 'an extension of everyday experience'. ${ }^{116}$ Thomas was convinced of the 'countryman's' experiential knowledge of the natural world, and of the ability of nature films to appeal to this experience while also communicating new knowledge. Their value lay 'not in the giving of new information, but in giving new significance to an already existing body of knowledge'.117 The idea that country people possessed some form of folk knowledge was also expressed in many Secrets, such as Swan Song (1938), which defers to a local breeder and his nephew for its information: 'Townspeople are always inquisitive when they talk to country people, so we'll do the same and ask how many swans he has'.

The use of Secrets as part of a WEA programme shows that biology films could be employed as powerful metaphors for discussing much broader discourses about society

113 National Union of Teachers, Sound Films in Schools, London: The Schoolmaster, 1931, p. 29.

114 National Archives, Kew, Board of Education, ED 11/239 'Denton experiment on the use of the cinema in public elementary school education', pp. 3-4.

115 F.G. Thomas, The New Learning: An Experiment with Educational Films in the County of Devon, London: WEA, 1932, p. 16.

116 Thomas, op. cit. (115), p. 36.

117 Thomas, op. cit. (115), p. 51. 


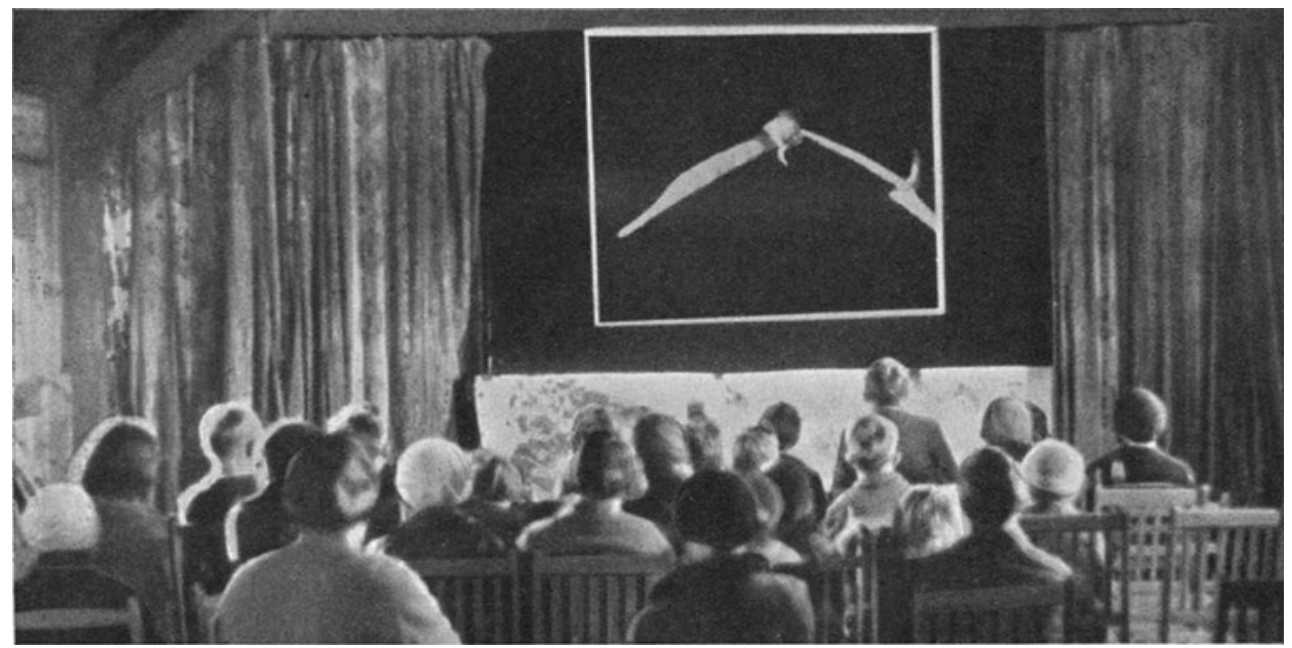

Figure 5. Audience watching a Secrets of Nature film as part of the New Learning experiment in Devon, 1932. Sight and Sound (1933) 1, p. 39. Photograph by Stuart Black.

and citizenship, from war to population control. ${ }^{118}$ The report's appendix records an extraordinary group conversation, transcribed after a screening of The Battle of the Ants (1922) and The Beehive (1926). A tutor asked several questions about how notions of community, cooperation and the nature of intelligence were reflected in the films. One woman, 'Housewife C', observed that 'if you take the trouble to watch an ant-hill-you can see nearly all that was on that film: and it is just the same with the bees. They all work on the same principle'. The conversation continued,

Tutor: Did those ants know they were fighting?

Housewife C: I certainly think they did

Postman: I should think so

Housewife C: If you destroy an ant-hill they will pick up their babies and carry them off to another place.

[The Farmer agreed.]

Housewife C: You cannot swear it is the same ants, but you have to take it for granted it is the same ants. Do not think that film was exaggerated a bit.

A Labourer: I think they happened to have got a very good example. What about that carrying away of the other ants' eggs?

Housewife A: Seemed very funny. They were already over-populated. That struck me as very peculiar, that they should have taken more eggs to hatch when they were already over-populated. ${ }^{119}$

118 Smith, op. cit. (21), p. 233.

119 Thomas, op. cit. (115), p. 61. 


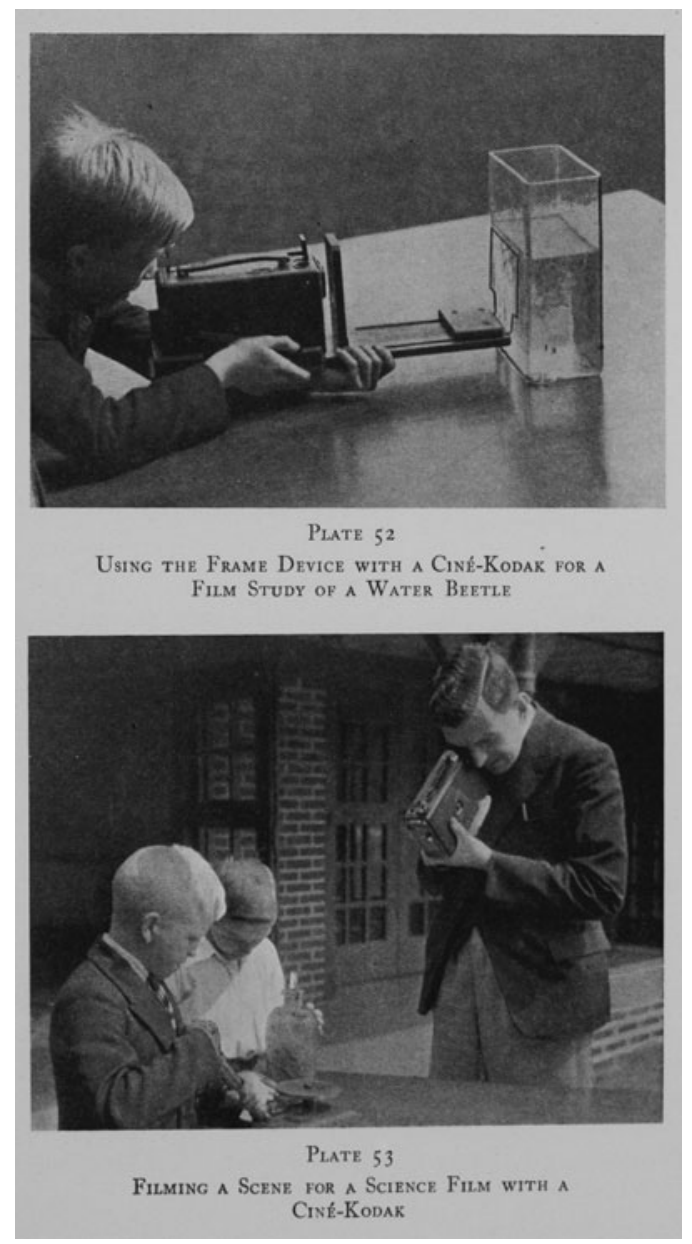

Figure 6. Ronald Gow teaches schoolchildren methods in ciné-biology. W.H. George, The Cinema in School, London: Pitman, 1935, p. 117.

This conversation suggests a critical, reflexive engagement by audiences with the content of Secrets films. Although we should not take it as representative of the 'average' audience response, it is illustrative of how nature films were often intended to be consumed in this period: not to transmit tangible scientific facts, but as a means to ignite the viewer's broader curiosity about these topics.

This is exactly how Ronald Gow, a teacher and later a well-known playwright, described the function of cinema in schools: 'as a "fact machine" the cinema has little or no place in education. But for stimulating the imagination and creating a background 
of interest in the pupils' work we find a definite value'. ${ }^{120}$ Alongside his students, Gow made The Sundew Plant, a surprisingly difficult first-choice film which mimicked the Secrets style. ${ }^{121}$ Ciné-biology could serve as a kind of object lesson: Figure 6 shows schoolchildren making their own films under Gow's supervision.

Secrets helped to situate film as part of the arsenal of methods available to amateur naturalists. It was common for natural history societies to have separate 'photography' sections alongside those for entomology or ornithology, and local scientific film societies also began to appear during this period. A 1934 review of the series in The Naturalist observed that 'many people will feel strongly tempted to take up nature cinematography', and Field too recognized that the films had inspired many 'enthusiastic amateurs'. ${ }^{122}$ Natural history became a common genre of amateur filmmaking in this period and in the post-war years, as illustrated by films like Betty and Cyril Ramsden's Winged Workers (1949). Oliver Sacks, moreover, recalled using a cinécamera as a child: 'I was able to catch the bumblebees at work as they hovered in the hollyhocks and to slow down their time-blurred wing beats. ${ }^{123}$ Nature films like Secrets, therefore, normalized the ciné camera as an indispensable tool in the study of natural history. They were made in the knowledge that viewers might wish to experience for themselves what they had seen on the screen. By attending closely to their audience's wishes, and by seeking to incorporate their suggestions, views and experiences, the Secrets films treated the public as co-producers.

\section{Conclusion}

Disney's Silly Symphonies were perhaps the closest comparable form of interwar entertainment to Secrets, and they frequently appeared side-by-side in newspaper advertisements. ${ }^{124}$ The Secrets films even 'tried to reproduce the Walt Disney technique, but with real animals': The Nightingale (1932) used synchronized music to give the impression of a bird dancing. ${ }^{125}$ Julian Huxley began advising Disney in 1940, when he was consulted for Fantasia, and he also worked on the True-Life Adventures. ${ }^{126}$ The fourth True-Life was called Secrets of Life, which could suggest that the Secrets were an inspiration for Disney's foray into live-action wildlife film. Huxley's collaborations in the 1950s with the young David Attenborough, moreover, provide a connecting thread between the films explored in this article and early natural history television. In

120 Ronald Gow, 'Films in school', International Review of Educational Cinematography (1931) 4, pp. 311-16.

121 Ronald Gow, 'Film-making at school', in J.A. Lauwerys (ed.), The Film in the School, London: Christophers, 1935, pp. 80-94.

122 'Secrets of nature', The Naturalist (1934) 59, p. 186. Field, op. cit. (45); Field and Smith, op. cit. (3), p. 48. See also Karen Lury, “'A constellation of incongruities”: the amateur film and the trip to the zoo', in Lawrence and Lury, op. cit. (29), pp. 3-21.

123 Oliver Sacks, The River of Consciousness, London: Picador, 2017, p. 28.

124 Surrey Mirror, 11 July 1930, p. 14. On anthropomorphism in cartoons see Paul Wells, The Animated Bestiary: Animals, Cartoons and Culture, New Brunswick, NJ: Rutgers University Press, 2009.

125 Field and Smith, op. cit. (3), p. 231.

126 Mitman, op. cit. (13), pp. 109-31. 
1937, Field presented a live television programme about making nature films, and Secrets films were frequently played on BBC Television in its experimental phase before the Second World War. ${ }^{127}$

The Secrets films, however, were far more than precedents to the 'age of Attenborough'. ${ }^{128}$ As this article has argued, they are valuable examples of the sorts of images, themes, ideas and discourses about nature which were in circulation in interwar Britain. Over the course of two decades, Secrets proved that the film medium could yield creative insights into scientific knowledge, while at the same time helping to forge a space for the life sciences in public culture. Crucially, they were embedded in an intermedial' culture of amateur natural history that reached a mass audience thanks largely to the emergence of daily newspapers, radio and cinema, as well as zoos and museums. Their production incorporated a wide range of ciné-biologists, including producers and scientific advisers, teachers and students, cinema audiences and even plants and animals. Tapping into interwar optimism regarding the role of modern technology in shaping public discourse, these actors co-produced ciné-biology, both as a cinematic genre with its own filmic grammar and as a scientific method. Ciné-biology also had democratic ambitions. Appealing directly to the experiences of viewers, the Secrets films did not just seek to humanize the natural world for its audiences on the screen, they also helped people to recognize nature as something which was at once closer to their own lives, and far more fascinating, than they previously imagined.

127 On similarities between the postwar television programme Look and Secrets see Tim Boon, 'Formal conventions in British science television, 1955-1965', Actes d'Historia de la ciència i de la tècnica (2014) 7, pp. 51-69.

128 Gouyon, op. cit. (12), pp. 9-11. 